\title{
Doména diletantství?
}

\section{Konference věnovaná stému výročí založení Státní archivní školy v Praze}

Katedra Pomocných věd historických a archivního studia FF UK ve spolupráci s Národním archivem uspořádala ve dnech 7.-8. listopadu 2019 mezinárodní konferenci Doména diletantství?, věnovanou stému výročí založení Státní archivní školy v Praze. Ta vznikla v roce 1919 jako samostatné, mimouniverzitní pracoviště, zaměřené výhradně na vzdělávání odborných archivářu pro tehdy nově vznikající sít' státních, později i soukromých a podnikových archivů Československé republiky.

Konference se konala v přednáškovém sále Národního archivu na Chodovci. Zahájil ji děkan Filozofické fakulty UK Michal Pullmann zdravicí účastníkům a připomenutím provázanosti historických oborů, mezi něž patř́i i jeho mateřské hospodářské a sociální dějiny a archivnictví a pomocné vědy historické, jimž byla konference věnována. Př́tomné účastníky pozdravila i zástupkyně ředitelky Národního archivu Zdeňka Kokošková a v neposlední řadě Ivana Ebelová, která se poprvé takto představila širší archivářské veřejnosti v postavení vedoucí Katedry PVHAS FF UK v Praze.

O úvodní referát se podělili Marie Bláhová a Jan Dobeš (oba PVHAS FF UK Praha). Připomněli okolnosti vzniku Státní archivní školy před sto lety, její významné učitele z řad vysokoškolských pedagogů i archivár̊o z praxe a pohnuté osudy Státní archivní školy během okupace v letech 1939-1945, kdy po část tohoto období stála pod nacistickou kontrolou.

První blok konference byl za moderování Thomase Vogtherra (Universität Osnabrück) věnován Výuce archivnictví v zahraničí. $\mathrm{V}$ jeho první části zastupoval svým vystoupením v Praze proslulou a pro středoevropský vývoj archivnictví zásadní marburskou archivní školu Robert Maier s referátem Archivausbildung in Deutschland: die Archivschule Marburg. Podal přehled historie marburské školy a představil její vedoucí osobnosti.

Tradičně výborné a inspirativní vztahy s polským archivnictvím se tu odrazily v referátech polských kolegů z Poznaně, Lublinu a Vratislavi. Irena Mamczak-Gadkowska (Poznań, UAM) promluvila o výuce archivnictví v Poznani (Z historii ksztatcenia archiwistów na Uniwersytecie im. Adama Mickiewicza w Poznaniu). Právním aspektům ve vzdělávání podnikových archivářu se věnoval Marek Konstankiewicz (Lublin, UMCS) v př́spěvku Elementy prawne w przygotowaniu zawodowym archiwisty - uwagi z perspektywy polskiej.

V druhé části bloku, moderovaném Marií Ryantovou (České Budějovice, JČU), zazněl dále referát Lucyny Harc (Wrocław, UW), postihující vývoj př́stupu k editorské praxi historických dokumentů pod názvem Od dyplomatyki i edytorstwa źródeł ku specjalności archiwalno-edytorskiej. Koncepcje kształcenia archiwistów na Uniwersytecie Wrocławskim prof. K. Maleczyńskiego i prof. W. Korty, a Janusze Łosowskiho (Lublin, UMCS), zamýšlející se nad polským pohledem na archivnictví jako samostatné vědy, Archiwistyka jako odrębna nauka? Polskie spojrzenie.

Janusz Łosowski se následně ujal moderování první části druhého bloku konference na téma Osobnosti archivnictví a PVH - I. Představitelé PVH pred zř́zením Státní archivni školy. Tady nejprve Thomas Vogtherr (Universität Osnabrück) představil významnou osobnost raně novověké vědy, Johanna Michaela Heineccia (1674-1722) jako jednoho ze zakladatelů sfragistiky co samostatné vědecké disciplíny (Johann Michael Heineccius und die Entstehung der Siegelkunde als wissenschaftliche Disziplin). Ema Šimková (Olomouc, UP) pak zahájila dlouhou řadu portrétů domácích představitelů archivnictví a pomocných 
věd historických, $\mathrm{v}$ jejím př́padě souborným referátem o vyučujících PVH v Olomouci (Pomocné vědy historické v publikacich profesorü historie c. $k$. Františkovy univerzity $v$ Olomouci). V tomto bloku se sál zaplnil ještě více, než tomu bylo v ostatních blocích konference, protože následoval referát Ivana Hlaváčka (Praha, FF UK) o Josefu Emlerovi. Bravurně přednesený príspěvek současné ikony českého archivnictví o jedné z hlavních minulých ikon nezklamal a opět zasáhl hloubkou lidského a zasvěceného Hlaváčkova pohledu na profesora Emlera, s mnoha detaily, rozšiřujícími znalosti o vývoji našeho oboru. V nelehké pozici po profesoru Hlaváčkovi nezklamala ani Marie Ryantová (České Budějovice, JČU) s rozborem okolností vzniku a obsahu Učebné knihy palaeografie latinské profesora Gustava Friedricha a výkladem o výuce paleografie už v rámci Státní archivní školy.

Tím se posluchači posunuli již do období existence Státní archivní školy. Jejím učitelům a absolventům byla věnována druhá část bloku Osobnosti archivnictví a $P V H$. Moderování se ujala nejdříve Irena Mamczak-Gadkowska. Do konce prvního dne konference tu ještě mohly být předneseny pohledy Hany Pátkové (Praha FF UK) na propojení Václava Hrubého $s$ archivní školou a mladého badatele Pavla Vaška (Praha, FF UK, NA) na Václava Vojtíška a jeho dlouhou archivářskou kariéru.

Po podnětné i kritické diskusi se účastníci přesunuli do prostorů Filozofické fakulty, kde byl připraven společenský večer.

Druhý den jednání pokračoval blok o Osobnostech archivnictví a PVH třetí částí, kterou moderovala Zdeňka Kokošková. Nejprve uvedla svého kolegu Jana Kahudu (Praha, NA) a jeho analytický prŕspěvek o Miloslavu Volfovi a jeho archivní příručce, která byla vydána v roce 1948. Doktorandi katedry PVHAS FF UK Kristýna Ansorgová a Jan Hanousek pak přednesli výsledek svého bádání o docentu Josefu Matouškovi, popraveném nacisty $\mathrm{v}$ listopadu 1939 společně s osmi studenty českých pražských vysokých škol. Vyjádřili se nejen k Matouškovým odborným aktivitám, ale i jeho politické angažovanosti. Citlivému tématu odstavení Jaroslava Prokeše (1895-1951), jednoho z ředitelů Státní archivní školy, ze všech pracovních pozic po roce 1945 i širšímu kontextu jeho profesního života se věnovala Milada Sekyrková (Praha, FFUK, ÚDAUK). Tuto část bloku uzavřel Vít Šmerha (Praha, Archiv ČVUT) diskusním př́ispěvkem o Trnité cestě Václava Lomiče aneb kapitolami z počátků Archivu ČVUT.

Poslední úsek konference, čtvrtou část bloku Osobnosti archivnictví a PVH, moderovanou Mladou Holou, přinesl tři referáty. Marta Hradilová (Praha, MÚA AV ČR) se podělila s př́tomnými o př́nos absolventů Státní archivní školy pro českou kodikologii, referátem nazvaným př́iznačně $Z$ nouze ctnost. Př́ínos Františka Hoffmanna (1920-2015) archivní teorii a metodice připomněla jeho o mnoho mladší kolegyně Hana Kábová (Praha, MÚA AV ČR). Závěr přednáškové části konference patřil Zdeňku Hojdovi a Martinu Kindlovi, kteří společnými silami poskládali mozaiku mnohostranné odborné činnosti Josefa V. Polišenského (1915-2001), jednoho z nejvýznamnějších absolventů Státní archivní školy.

Po dlouhé diskuzi přitomných shrnula Ivana Ebelová výsledky celého jednání a vyjádřila přesvědčení, že katedra bude pořádat podobné konference a další typy setkávání archivářů $\mathrm{v}$ určitých intervalech, aby se nepřerušila kontinuita spolupráce mezi archivy a př́buznými institucemi jak v rámci republiky, tak se zahraničím. 